2. Дрожжин В. Правосудие в Древнем Риме // Российская юстиция. - 1994. - № 10. - С. 34

3. Российская Федерация. Законы. Конституция Российской Федерации [принята всенародным голосованием 12.12.1993 г.] // СПС «КонсультантПлюс».

4. Закатов А. А. Ложь и борьба с нею. - Волгоград, 1984. - С. 46-47

5. Смолина Л. А. Очная ставка в гражданском процессе. Проблемы судопроизводства по делам, возникающим из гражданских и административных правоотношений // Сборник статей по материалам международной научно-практической конференции. Северо-Западный филиал ФГБОУВО «Российский государственный университет правосудия». - 2017. - С. 225-229.

6. Петров, И. В. Новеллы гражданского кодекса России по обеспечению исполнения обязательств / И. В. Петров, И. И. Дементеева // Актуальные проблемы реформирования гражданского и предпринимательского права : Материалы Всероссийской очно-заочной научно-практической конференции с иностранным участием, Краснодар, 02-03 октября 2015 года / СКФ ФГБОУВО «Российский государственный университет правосудия». - Краснодар: Общество с ограниченной ответственностью "Издательский Дом - Юг", 2015. С. $35-42$.

7. Петров, И. В. Социально-правовая ответственность в предпринимательской деятельности / И. В. Петров, И. И. Дементеева // Национальные экономики в условиях глобальных и локальных трансформаций : Сборник статей международной научно-практической конференции, Москва, 23-28 октября 2018 года / Под ред. Г.Б. Клейнера, Х.А. Константиниди, В.В. Сорокожердьева. - Москва: АНО "Научно-исследовательский институт истории, экономики и права", 2018. - С. 77-80.

\title{
Кирушин К.Р., Хисматов Р.С. Эволюция советской судебной системы на примере уголовных дел Набережночелнинского городского суда
}

Набережночелнинский государственный педагогический университет (Россия, Набережные Челны)

doi: 10.18411/trnio-01-2022-174

\section{Аннотация}

Данная работа рассматривает процесс становления и развития судебной практики в Советском Союзе во второй половине XX века. Описана история трансформации судебной системы Советского Союза. Рассмотрена проблематика позднесоветской судебной практики и судоустройства на Всесоюзном и региональном уровне.

Ключевые слова: Советский Союз, судебная практика, уголовное дело, суд, судоустройство.

\section{Abstract}

This work examines the process of formation and development of judicial practice in the Soviet Union in the second half of the XX century. The history of the transformation of the judicial system of the Soviet Union is described. The problems of late Soviet judicial practice and judicial system at the All-Union and regional levels are considered.

Keywords: Soviet Union, judicial practice, criminal case, court, judicial system.

Актуальность научной работы заключается в изучении советской судебной системы во второй половине существования Советского государства. Основной упор делается на изучении судебной практике в регионе. Есть множество научных и публицистических работ, касательно судебного обоснования политических репрессий в Советском Союзе, особенностей судебного рассмотрения резонансных уголовных дел, особенностей советского судопроизводства, в нашей работе акцент сделан на уголовных делах, которые в большей степени отражают повседневность советского общества, взаимодействие общества и государства.

Первый этап истории советской судебной системы начался с декрета Совета Народных Комиссаров от 22 ноября 1917 года «О суде» № 1. Согласно декрету: учреждались народные суды в составе постоянного судьи и 2 народных заседателей, которые сменяли дореволюционные мировые суды; вводилось выборность судейского корпуса; допускалось 
использование дореволюционного законодательства, при условии, если оно не противоречит нормативно-правовым актам новой власти, революционному правосознанию.

Следующим законодательным актом стал декрет Всероссийского центрального исполнительного комитета (ВЦИК) и Совета Народных Комиссаров (СНК) от 15 февраля 1918 года «О суде» № 2. Предусматривалось создание окружных народных судов, рассмотрение гражданских дел в составе 3 постоянных судей 4 народных заседателей, рассмотрение уголовных дел в составе 12 народных заседателей под председательством постоянного судьи. Также учреждались областные суды для рассмотрения дел в кассации.

Последующие реформы власти большевиков были направлены на усовершенствование судебной системы, системы защитников обвиняемых и внедрение в суд состязательность сторон.

Второй крупный этап в истории советского судоустройство начался 30 ноября 1918 года, когда было принято «Положение о народном суде РСФСР». Положение отменяло старое устройство судебной власти и создавала новую. Началось образование районных и городских судов, к подсудности которых переходили все уголовные и гражданские дела, за исключением дел контрреволюционной деятельности, которые остались введении Всероссийской чрезвычайной комиссии по борьбе с контрреволюцией и саботажем (ЧК). Более суды не имели права опираться на законы Царской России - теперь суды должны были исходить из принятых Советами декретов или, в случае отсутствия новой законодательной нормы, так называемым революционным правосознанием. Суд самостоятельное избирал меру пресечения, и выносил приговор. В каждой губернии учреждался более крупный орган судебной власти - Совет народных судей куда можно было подать кассацию на обжалование приговора, сроком на 1 месяц со дня вынесения приговора. Наиболее опасные дела рассматривали специально сформированные комиссии в губернии или уезде.

Oсобое место в советском судоустройстве занимали революционные трибуналы, учрежденные еще первым декретом «О суде». декрет Совета Народных Комиссаров от 4 мая 1918 года и Положения о революционных трибуналах от 12 апреля 1919 года и от 18 марта 1920 года уточняли работу революционных трибуналов: были определены границы подсудности дел, указывался состав трибунала, а также порядок и сроки обжалования решений трибунала.

Третьим крупным этапом в истории советской судебной системы является судебная реформа 1922 года, по которой были изданы Положения об адвокатуре и Положения о прокуратуре.

В 1922 году по окончанию гражданской войны ВЦИК утвердил «Положение о судоустройстве РСФСР». Вводилась трехзвенная система из районных, областных и республиканских судов, высшем судебным органом становится Верховный суд РСФСР, однако для рассмотрение специфических дел по степени востребованности могла быть образованная специальная судебная комиссия, которая в свою очередь требовала бы специальных познаний.

Главным звеном в судебной системе стал районный народный суд, работающий в составе постоянного судьи и 2 народных заседателей, именно районный суд взял на себя значительную массу уголовных и гражданских дел, областной или же республиканский суд остался кассационной инстанцией для районных народных судов, а также рассматривал особо тяжкие преступления. Верховный суд РСФСР стал надзорным органом, суд вел контроль судопроизводства в республиканских и областных судах, имел право в порядке надзора запрашивать любые уголовные или гражданские дела, по которым были уже вынесены приговоры районными или областными судами.

С образованием СССР изменения претерпевает прокуратура, так к примеру, в 1933 году вместо Прокурора Верховного суда СССР была учреждена должность Прокурора СССР, таким образом появился отдельный надзорный орган - прокуратура, положение о прокуратуре Союза СССР от 17 декабря 1933 года, возложило на прокуратуру. 
1. Надзор за соответствием Конституции СССР нормативно-правовых актов ведомств СССР, союзных республик и местных органов власти, постановлениям и распоряжениям правительства.

2. Наблюдение за правильным и единообразным применением законов судебными учреждениями.

Следующим этапом реформирования советского судоустройства стал Закон «О судоустройстве СССР» 1938 года, в котором определили следующие основы судебной системы: суды СССР (Верховный суд, военные трибуналы, линейные суды железнодорожного и водного транспорта) и суды союзных республик (верховные суды союзных республик, областные и равные им суды, народные и равные им суды). Судьи народного суда стали избираться на три года. Судьи остальных судов избирались Советами на пять лет.

Таким образом можно отметить, что проводимые реформы ставили целью переустройство конфигурации судебной власти. Реформы 1922-1938 годов сыграли ключевую роль в последующих судебных реформах в Советском Союзе, многие элементы были сохранены и лишь изменены.

Великая Отечественная война оставила свой отпечаток на судебной системе Советского Союза, начавшаяся война ужесточила судебную систему, принятые постановления и положения были направлены на максимальное ускорение судопроизводства. Значительно расширялись права военных трибуналов, упрощен и сокращён срок судебного разбирательства, а также сокращен до 48 часов срок обжалования решений. Расширяется законодательно и в применении административное (внесудебное) разбирательство, приговоры по которым приводились в исполнение незамедлительно. Были созданы военно-полевые суды, которые действовали в составе председателя военного трибунала дивизии, начальника дивизионного отдела «СМЕРШ», заместителя командира дивизии по политчасти и прокурора дивизии.

Великая Отечественная война сильно изменила судебную систему. Условия военного времени требовали ускоренного рассмотрения дел и исполнения наказания. Некоторые элементы судебной системы видоизменялись (упрощенной порядок судебного рассмотрения дел, усиление роли административного порядка отправления правосудия), а часть уходила в прошлое (выборность судей).

В 1953 году после смерти Сталина начинается так называемый период «Оттепели», новое советское руководство берёт курс на сворачивание репрессивной системы в СССР, упразднены военные трибуналы и прокуратуры в войсках МВД СССР, органы внесудебной репрессии, упрощенный порядок рассмотрения дел о государственных преступлениях. Начался процесс реабилитации невинно осужденных граждан, обвиненных в большинстве своем по политическим статьям, объявленных врагами народа. 24 мая 1955 года было принято положение о прокурорском надзоре в СССР.

Высшим судебным органом СССР оставался Верховный суд СССР, на который возлагался надзор за судебной деятельностью судов СССР. Было принято «Положение о Верховном суде СССР» (12 февраля 1957 года), которое значительно расширяло права судебных органов союзных республик. До 1957 года Верховный суд СССР был наделен правом востребовать любое дело из любого суда, даже когда оно еще не рассматривалось Верховным судом республики. Новое положение предусматривало, что все дела должны окончательно решаться в Верховном суде союзной республики, а Верховный суд СССР может пересматривать решение суда республики, только если оно противоречит общесоюзному законодательству или интересам другой республики.

Новый Закон СССР «О Верховном суде СССР» был принят 30 ноября 1979 года. Закон устанавливал, что Верховный суд СССР выступает в качестве суда первой инстанции, рассматривает дела в кассационном порядке, в порядке надзора и по вновь открывшимся обстоятельствам. Он разрешал в пределах своих полномочий вопросы, вытекающие из международных договоров СССР. Верховный суд СССР избирался Верховным Советом 
СССР сроком на пять лет. Кроме того, в его состав входили председатели Верховных судов союзных республик. Верховный суд СССР действовал в составе Пленума, трех коллегий по гражданским, уголовным и военной делам.

Для анализа судебной практики позднего Советского Союза, были взяты приговоры по уголовным делам, рассмотренные Набережночелнинском городским судом Республики Татарстан, в настоящие время хранящиеся в Архивном отделе Исполнительного комитета города Набережные Челны. Для изучения были взяты единицы хранения фонда № 1044.

Всего было изучено 14 единиц хранения фонда №1044 за 1983г., 1989г. В общей сложности в ходе исследования было обработано 307 приговоров, 145 из которых были вынесены в 1983 году, а 162 были вынесены в 1989 году — то есть в годы разных эпох Советского Союза, которые в современной историографии называются «эпоха Застоя» (1961-1985) и «Перестройка» (1985-1991).

Для изучения и анализа судебной практики, согласно принятой цели исследования, были отобраны дела, которые затрагивали интересы и благополучие государства: кража и воровство социалистической собственности; мелкое хулиганство; незаконное производство и ношение оружия; подделка и сбыт документов; покушение на жизнь представителей власти и лиц, исполняющих общественный долг. Из списка дел для детального и углубленного изучения, и анализа были исключены дела, которые хоть и были совершенны общественно опасным способом, но затрагивали частные интересы (то есть дела частного и частнопубличного обвинения): разбои; кражи частного имущества; воровство; грабежи; нанесение телесных повреждений разной степени тяжести.

Общая статистика по всем изученным приговорам (включая те, которые позже были удалены из списка для углубленного анализа) выглядит следующим образом: 307 приговоров из 307 были обвинительными; 1 приговор из 307 был изменен в части сроков наказания в сторону уменьшения срока; 0 из 307 реабилитаций; 0 из 307 приговоров были отменены по различным причинам в вышестоящих инстанциях.

Статистика по отобранным для анализа делам:

- Статья 89 («Хищение государственного или общественного имущества, совершенное путем кражи») - 3 дела;

- Статья 92 («Хищение государственного или общественного имущества, совершенное путем присвоения или растраты либо путем злоупотребления служебным положением») - 2 дела;

- Статья 93 («Хищение государственного или общественного имущества, совершенное путем мошенничества») - 1 дело;

- Статья 96 («Мелкое хищение государственного или общественного имущества») - 1 дело;

- Статья 121 («Мужеложство») - 1 дело;

- Статья 154 («Спекуляция») - 1 дело;

- Статья 170 («Подделка в корыстных целях официальных бумаг, документов и расписок») - 1 дело;

- Статья 193 («Угроза или насилие в отношении должностного лица или гражданина, выполняющего общественный долг») - 1 дело;

- Статья 196 («Подделка, изготовление или сбыт поддельных документов, штампов, печатей, бланков») - 2 дела;

- Статья 206 («Хулиганство») - 3 дела.

Анализ изученных приговоров по уголовным делам позволяет сделать следующие выводы.

1. Совершенные преступления были явны и очевидно доказуемы: наличие свидетелей, поимка преступников на месте преступлений. 
2. Подозреваемые признавали свою вину, а часть из них совершали деятельное раскаяние (частично возвращали украденные денежные средства или вещи, в меру возможностей восстанавливаю ущерб).

Исходя их этих пунктов, можно утверждать, что первая вышеуказанная причина обвинительных приговоров подтверждена. При этом надо отметить, что не имеется объективных данных по числу дел, что не дошли до судебного разбирательства, ввиду чего невозможно сопоставить две группы, дошедших дел и не дошедших, и выявить пропорциональные соотношения.

Касательно приговоров можно также отметить и избираемые меры наказания, которые в большинстве своём, хоть и учитывали смягчающие обстоятельства (основным из которых является признание вины и деятельное раскаяние), но не часто были по минимальной санкции, предусмотренные статьями Уголовного кодекса РСФСР. Особенно эта тенденция назначения наказания явно выше минимального прослеживается в приговорах эпохи «Застоя». В «Перестройку» отмечается обратная тенденция - применение минимальной санкции при возможности.

Также отдельно стоить отметить характер советского судопроизводства, каждое отдельное взятое дело рассматривается не как частное преступление против человека, гражданина, или же имущества, а как злостное преступление против государства, к примеру, в приговоре суда всегда указывается фраза «На основании вышеизложенного, руководствуясь статьями УК РСФСР народный суд приговорил», таким образом можно провести прямую параллель между обществом и государством, т.е. суд осуществляет свою деятельность не с позиции государства как отдельно взятого органа власти а с позиции народа и общества, поэтому советскую систему нельзя рассматривать с позиции частного лица, или частного имущества, в Советском Союзе любое преступление можно назвать антигосударственным, ведь оно было направленно против советского народа, будь то воровство, грабеж, подделка документа и т.д.

$$
\text { *** }
$$

1. Архивный отдел управления делопроизводства Исполнительного комитета муниципального образования город Набережные Челны Ф. №1044, О. №3, Ед. Хр. №751-757.

2. Архивный отдел управления делопроизводства Исполнительного комитета муниципального образования город Набережные Челны Ф. №1044, О. №3, Ед. Хр. №1317-1321.

3. Декрет Совета Народных Комиссаров (О суде). // Сайт Конституции Российской Федерации [Электронный доступ]. - URL: https://constitution.garant. ru/history/act1600-1918/5312/ (дата обращения 02.12.2021)

4. Декрет ВЦИК и СНК о суде № 2. // Сайт Электронная библиотека исторических документов [Электронный доступ]. - URL: http://docs.historyrussia.org/ru/nodes/9898 (дата обращения 02.12.2021)

5. Положение ВЦИК о народном суде РСФСР. // Сайт Электронная библиотека исторических документов. [Электронный доступ]. - URL: http://docs.historyrussia.org/ru/nodes/10148-30-noyabrya-polozhenie-vtsik-onarodnom-sude-rsfsr\#mode/inspect/page/1/zoom/4 (дата обращения 04.12.2021)

6. Декрет ВЦИК от 12.04.1919 "О революционных трибуналах (Положение)". // Сайт КонсультантПлюс. [Электронный доступ]. - URL:

https://www.consultant.ru/cons/cgi/online.cgi?req=doc\&base=ESU\&n=40342\#7HrZcsSC7f5CONQk (дата обращения 04.12.2021)

7. Декрет ВЦИК от 12.04.1919 "О революционных трибуналах (Положение)". // Сайт КонсультантПлюс. [Электронный доступ]. - URL:

https://www.consultant.ru/cons/cgi/online.cgi?req=doc\&base=ESU\&n=40342\#7HrZcsSC7f5CONQk (дата обращения 05.12.2021)

8. Декрет ВЦИК от 18.03.1920 "О революционных трибуналах (Положение)". // Сайт КонсультантПлюс. [Электронный доступ]. - URL:

https://www.consultant.ru/cons/cgi/online.cgi?req=doc\&base=ESU\&n=16940\#W9JacsSWyJvqlUEl (дата обращения 09.12.2021)

9. Постановление ВЦИК от 11.11.1922 "О введении в действие Положения о судоустройстве Р.С.Ф.С.Р.". // сайт КонсультантПлюс. [Электронный доступ]. - URL:

https://www.consultant.ru/cons/cgi/online.cgi?req=doc\&base=ESU\&n=8322\#WfTkcsSch5rdDjUr (дата обращения 09.12.2021) 
10. Постановление ЦИК СССР №84, СНК СССР №2621 от 17.12.1933 «Положение о прокуратуре Союза ССР».

// Сайт КонсультПлюс [Электронный доступ]. - URL: http://www.consultant.ru/cons/cgi/online.cgi?req=doc\& base $=\mathrm{ESU} \& \mathrm{n}=31115 \# \mathrm{q} 9 \mathrm{X} 5 \mathrm{xrSvUPJjVFC}$ (дата обращения 10.12.2021)

11. Указ Президиума ВС СССР от 24.05.1955 "Об утверждении Положения о прокурорском надзоре в СССР". // Сайт КонсультантПлюс. [Электронный доступ]. - URL:

https://www.consultant.ru/cons/cgi/online.cgi?req=doc\&base=ESU\&n=19140\#in9lcsSftq227hE (дата обращения 10.12.2021)

12. Закон СССР от 12.02.1957 "Об утверждении Положения о Верховном Суде СССР и о внесении изменений и дополнений в статьи 104 и 105 Конституции (Основного Закона) СССР". // Сайт КонсультантПлюс.

[Электронный доступ]. - URL:

https://www.consultant.ru/cons/cgi/online.cgi?req=doc\&base=ESU\&n=7539\#LrOlcsSqaIrmApt4 (дата обращения 11.12.2021)

13. Закон СССР от 30.11.1979 "О Верховном Суде СССР". // Сайт КонсультантПлюс [Электронный доступ]. URL: https://www.consultant.ru/cons/cgi/online.cgi?req=doc\&base=ESU\&n=1624\#RKjlcsS8e8Rp8HE21 (дата обращения 11.12.2021)

\author{
Ковтун Е.А. ${ }^{1}$, Удалов Д.Э. $^{2}$ \\ Вопросы правового регулирования занятости населения \\ ${ }^{1}$ ФГАОУ ВО «Национальный исследовательский университет «Высшая школа экономики» \\ ${ }^{2}$ ФГОБУ ВО «Финансовый университет при Правительстве Российской Федерациии»
}

doi: 10.18411/trnio-01-2022-175

(Россия, Москва)

\title{
Аннотация
}

В статье рассматриваются правоотношения, возникающие в процессе реализации службами занятости полномочий по реализации принципов государственной политики, направленной на обеспечение занятости, в рамках социальной работы с населением. Анализируются положения нормативно-правовых актов, гарантирующих права граждан в области занятости, профессиональной подготовки и профессиональной ориентации в целях приобретения новых трудовых навыков и трудоустройства.

Ключевые слова: труд, трудовые отношения, занятость, социальные права, социальная работа, правовое регулирование.

\section{Abstract}

The article considers legal relations arising in the process of exercising the powers of the employment services to implement the principles of state policy aimed at ensuring employment in the framework of social work with the population. The provisions of the regulations guaranteeing the rights of citizens in the field of employment, vocational training and vocational guidance in order to acquire new labor skills and employment are examined. regulation.

Keywords: labour, labour relations, employment, social rights, social work, legal

Социальные отношения, составляют основу жизнедеятельности человека и включают в себя широкий спектр отношений, возникающих, в частности в процессе, осуществления трудовой деятельности. Одной из актуальных проблем современного общества является проблема обеспечения занятости населения. С целью решения данной проблемы, уполномоченными органами государства, осуществляются мероприятия в рамках социальной работы с населением.

Государство как важнейший социально-политический институт ответственен за благоприятные условия индивидуальной и групповой жизнедеятельности, в том числе в сфере труд, за реализацию механизмов социального контроля, регламентацию профессиональных видов деятельности. Современная рыночная экономика ставит ряд задач, главнейшей из которых становится максимально эффективное использование кадрового 